\title{
1 Earlier springs enable High-Arctic wolf spiders to produce a second clutch
}

2

3 Toke T. Høye ${ }^{1, *}$, Jean-Claude Kresse ${ }^{1}$, Amanda M. Koltz ${ }^{2}$ and Joseph J. Bowden ${ }^{3}$

4

5 1. Arctic Research Centre and Department of Bioscience, Grenåvej 14, DK-8410 Rønde, Aarhus

6 University. Denmark

7 2. Department of Biology, Washington University in St. Louis, Box 1137, St. Louis, MO 63130

8 3. Canadian Forest Service - Atlantic Forestry Centre, 26 University Drive, PO Box 960, Corner Brook, NL, Canada A2H 6J3

10

$11 *$ corresponding author, tth@ bios.au.dk, phone: +4587158892

12

13 Key words: Arthropods, Climate change, Life history variation, Phenology, Reproduction 


\section{ABSTRACT}

15 Spiders at southern latitudes commonly produce multiple clutches, but this has not been observed at high latitudes where activity seasons are much shorter. Yet the timing of snowmelt is advancing in the Arctic, and may allow some species to produce an additional clutch. To determine if this is already happening, we used specimens of the wolf spider Pardosa glacialis caught by pitfall traps from the long-term (1996-2014) monitoring program at Zackenberg, Northeast Greenland. We dissected individual egg sacs and counted the number of eggs and partially developed juveniles, and measured carapace width of the mothers. Upon discovery of a bimodal frequency distribution of clutch sizes, as is typical for wolf spiders at lower latitudes producing a second clutch, we assigned egg sacs to being a first or second clutch depending on clutch size. We tested whether the median capture date differed among first and second clutches, whether clutch size was correlated to female size, and whether the proportion of second clutches produced within a season was related to climate. We found that assigned second clutches appeared significantly later in the season than first clutches. In years with earlier snowmelt, first clutches occurred earlier and the proportion of second clutches produced was larger. This result, likely a result of female spiders producing first clutches earlier in those years, which allowed time for another clutch. Clutch size for first clutches was correlated to female size, while this was not the case for second clutches. Our results provide the first evidence for Arctic invertebrates producing additional clutches in response to warming. This could be a common but overlooked phenomenon due to the challenges associated with long-term collection of life history data in the Arctic. Moreover, given that wolf spiders are a widely

34 distributed, important tundra predator, we may expect to see population and food web consequences 35 of their increased reproductive rates. 


\section{INTRODUCTION}

Shifts in phenology, i.e. the timing of biological events, are the most widely reported biological response to climate change [1-3]. The demographic consequences of climate-induced phenological variation are typically studied in the context of phenological mismatch, where mistiming of resource availability and resource demand lead to reduced growth, survival, or reproduction [4-6]. Some studies have examined how the number of generations per year may increase in response to a warmer climate [7-9], but little is known about how extended growing seasons may affect total reproductive output $[10,11]$. Yet warmer conditions can extend the time available for reproduction, which may result in phenological shifts that could also affect demography and population dynamics [12]. Due to the low temperatures and time limitations of short growing seasons in northern environments, invertebrate organisms that typically produce multiple clutches in temperate ecosystems can typically only produce one clutch at higher latitudes $[13,14]$. Arctic temperatures are currently rising at twice the global average and climate projections indicate that the Arctic will continue to warm at a higher rate than the rest of the globe [15]. These warmer conditions and associated extended growing seasons may result in higher reproductive rates among Arctic species that are opportunistically capable of producing additional clutches.

Arctic arthropods are expected to be particularly affected by climate, and changes in their phenology have been widely documented [16-18]. Wolf spiders (family: Lycosidae) are abundant on the Arctic tundra [19-23] and they play an important role as top predators in the ecosystem [24-26]. They are also very responsive to environmental change [27, 28]. In the North, their life cycle typically takes two or more years $[29,30]$, while in the temperate zone, wolf spiders have annual life cycles [31]. Adult spiders die after completing reproduction, but female wolf spiders at lower latitudes typically produce more than one clutch over their lifetimes [32, 33]. Subsequent egg clutches are produced approximately one month after the first clutch, and they 
60 differ from first clutches in that there are typically fewer eggs produced per clutch [32]. In the

61 Arctic, due to the time constraints of extremely short growing seasons, female wolf spiders have always been assumed to produce only one clutch [34]. However, the opportunity to produce a second clutch could confer a big fitness advantage, which may be possible with the warmer temperatures and extended growing seasons that are currently being brought on by climate change [35]. The characteristics associated with the production of second clutches in temperate regions suggest that if longer growing seasons enable female wolf spiders in the Arctic to produce second clutches, these clutches would likely occur later in the summer, contain fewer eggs per clutch, and occur more frequently in years with early snowmelt or higher temperatures. invertebrates [36], including among spiders, whereby larger females produce larger clutches [37, 38]. Body size - and hence fecundity - also vary according to growing season length in these organisms. For example, previous studies from multiple Arctic locations have found that wolf spider body size and fecundity decrease with rising elevation, a proxy for shortening growing season length [39] [40]. Whether larger females are also be more likely to produce second clutches is unknown. We would expect body size of females producing a second clutch to be larger if only the biggest individuals are able to produce two clutches, or alternatively, females should be of similar size if the ability to produce two clutches mainly depends on the length of the season.

Here, we use long-term (1996-2014) data on clutch size variation in the only wolf spider species (Pardosa glacialis, Thorell 1872) known from the study area at Zackenberg, NE Greenland to examine if climate change is enabling the spiders to produce an additional clutch through a 
84 Greenland is resulting in warmer summer temperatures and earlier spring snowmelt/growing season

85 [42]. We argue that the combination of three patterns would indicate that second clutches are produced in a population: 1) A bimodal frequency distribution of clutch sizes which would allow for an assignment of clutches to either first or second clutches. 2) Females with egg sacs assigned to first clutches should be caught earlier than those females with egg sacs assigned to second clutches.

3) Females producing clutches assigned as first clutches should not be bigger than females carrying egg sacs that are assigned as second clutches. We use data from a long-term (1996-2014) standardized monitoring program at Zackenberg in High-Arctic Greenland to examine the likelihood of whether second clutches are being produced by female wolf spiders. We make the following predictions in light of climate change: 1) A proportion of all egg sacs are from second clutches, 2) that this proportion varies across years at the site, and 3) the proportion of second clutches is related to timing of snowmelt date.

\section{MATERIALS AND METHODS}

\section{Field and lab work}

Female wolf spiders carry their egg sac attached to their spinnerets, and therefore pitfall trap

103 the Greenland Ecosystem Monitoring program. The plots are placed in three different habitats with 104 one plot in a fen and two plots each in mesic heath and arid heath habitats. Pitfall traps were 105 emptied weekly during June, July and August, although trapping continued into September in a few 106 years. In order to standardize trapping effort, we omitted samples (totalling 17 egg sacs) collected 107 before 1 June and after 27 August. Only one species of wolf spider (P. glacialis) has been collected 
108 from the study area over this 18 year period [27], so all egg sacs are assumed to belong to this

109 species. The species has a generation time of two years at the site [41]. All egg sacs from years

110 1996-2014 (no available data for 2010) were opened. We counted the number of eggs or partially

111 developed juveniles. If the egg sac was still attached to the mother, we measured the width of her

112 carapace to the nearest $0.01 \mathrm{~mm}$ using a reticle fitted to a stereo microscope. Otherwise, the mother

113 could only be identified if there was only one female in the sample. A total of 1069 egg sacs were

114 collected across the 18 years of sampling. The mother could only be confidently identified in 280 of

115 these cases due to egg sacs detaching from the mother during trapping. We calculated the date of

116 snowmelt across plots as the average date at which $50 \%$ of the snow had disappeared from each plot

117 during spring snowmelt, measured as the day of the year after 1 January.

119 Data analysis

120 We found a clear bimodal frequency distribution of the sizes of clutches and could therefore assign

121 each clutch to a first or second clutch depending on clutch size. We tested if there was a significant

122 difference in the mean capture dates between egg sacs that were assigned to first or second clutches

123 using a one-way ANOVA. We then tested whether the proportion of second clutches produced

124 across years varied among habitat types. Likewise, we tested whether this proportion exhibited a

125 trend across the study period or was related to the date of snowmelt using general linear models

126 with a Gaussian error distribution. We also tested if the mean date of trapping first clutches was

127 related to timing of snowmelt. Finally, for the subset of data for which the mother could be

128 identified, we tested if clutch size was related to body size of the mother separately for first and

129 second clutches. For this subset, we also tested if mothers that were assigned to first or second

130 clutches differed in body size using a general linear model. All analyses were conducted in R ( R

131 Core Development Team 2016). 


\section{RESULTS}

134 Clutch sizes exhibited a distinct bimodal distribution with a split between peaks of clutch size at 47

135 eggs (Figure 1). We assigned clutches with more than 47 eggs to first clutches and considered

136 clutches with 47 eggs or less to be second clutches. Clutches with 47 eggs or less were caught

137 significantly later in the season than larger clutches (difference $=20.7 \pm 1.3$ days, $F_{1,1067}=253.6$,

$138 \mathrm{p}<0.001$; Figure 2). The same was true within individual years based on comparisons of the average

139 dates of at least ten egg sacs in first and second clutches (data not shown). Of the 17 omitted egg

140 sacs collected after 27 August, 15 (88\%) had 47 eggs or less and, therefore, would have been

141 assigned to second clutches. Across all years, the proportion of second clutches varied among

142 habitats and was highest in the wet fen (arid heath $=0.113$, mesic heath $=0.128$, and wet fen $=$

$1430.543)$.

144 Snowmelt advanced significantly during the study period (slope $=-0.79 \pm 0.36, \mathrm{R}^{2}{ }_{\text {adj }}=$

$1450.18, \mathrm{n}=18, \mathrm{p}=0.043$ ). We found a negative relationship between the proportion of second

146 clutches and date of snowmelt (slope $=-0.015 \pm 0.0038, \mathrm{R}_{\text {adj }}^{2}=0.46, \mathrm{n}=18, \mathrm{p}=0.0012$; Figure $3 \mathrm{a}$ )

147 and sampling year (slope $=0.0182 \pm 0.0075, \mathrm{R}_{\text {adj }}^{2}=0.22, \mathrm{n}=18, \mathrm{p}=0.028$; Figure $3 \mathrm{~b}$ ). We also

148 found earlier mean capture date of first clutches in years with earlier snowmelt (slope $=0.90 \pm 0.20$,

$149 \mathrm{R}^{2}{ }_{\mathrm{adj}}=0.54, \mathrm{n}=18, \mathrm{p}=0.0032$ ). Clutch size of first clutches was largest in wet habitats,

150 intermediate in mesic habitats and smallest in arid habitats (arid vs. wet $=28.40 \pm 3.29, \mathrm{t}=8.65, \mathrm{p}<$

$1510.001 ;$ arid vs. mesic $=5.66 \pm 1.56, \mathrm{t}=3.63, \mathrm{p}=0.00035)$ and was positively related to carapace

152 width of the mother (estimate $=68.48 \pm 5.15, \mathrm{t}=13.29, \mathrm{p}<0.0001$; Figure $4 \mathrm{a})$. The size of second

153 clutches was independent of habitats (arid vs. mesic $=0.60 \pm 3.93, \mathrm{t}=0.15, \mathrm{p}=0.88$; arid vs. wet $=$

$1542.45 \pm 4.10, \mathrm{t}=0.60, \mathrm{p}=0.56)$ and unrelated to carapace width of mothers (estimate $=3.10 \pm 8.2, \mathrm{t}=$ 
$1550.38, p=0.71$; Figure $4 b)$. There was no significant difference in body size between mothers of first

156 and second clutches (difference $=-0.0039 \pm 0.025, \mathrm{~F}_{1,278}=0.024, \mathrm{p}=0.88$ ).

157

158

159

160

161

162

163

164

165

166

167

168

169

170

171

172

173

174

175

176

177

178

\section{DISCUSSION}

Over the last two decades, the climate at Zackenberg has changed significantly, including snowmelt occurring progressively earlier and temperatures becoming warmer. These changes have had rapid measurable impacts on the biology of species in the area [43, 44]. In addition to previously documented changes, we have detected strong evidence of climate change induced shifts to multivoltinism in a dominant spider species. Our results provide the first evidence of an arctic spider species being able to produce two clutches. This is demonstrated by a striking bimodal frequency distribution of clutch sizes in the wolf spider $P$. glacialis, which is indicative of second clutches in temperate regions $[32,45]$. Moreover, clutches with fewer eggs (47 eggs or less) were produced significantly later in the season than larger clutches. We are able to rule out the possibility that this was driven by inter-annual variation in egg sac phenology, because second clutches were laid later in the season in all years. Together, these findings provide support for the hypothesis that P. glacialis is able to produce a second clutch at our high-arctic study site in North-East Greenland. We were further able to demonstrate that as spring snowmelt becomes earlier, a greater proportion of $P$. glacialis females are able to produce a second clutch and that the production of second clutches is increasing over time. In fact, the proportion of second clutches increased from zero to $>50 \%$ as snowmelt became progressively earlier over the study period, suggesting that the ability to produce second clutches is a common yet overlooked phenomenon in northern ecosystems.

It is known that larger female wolf spiders produce more offspring [46] and our results confirm this for first clutches. However, we found no indication that larger females are more likely to produce a second clutch than smaller females or that larger females produce larger second 
179 clutches. These findings suggest that the production of second clutches in association with earlier

180 snowmelt is not due to females obtaining more resources and attaining larger body sizes. Rather,

181 earlier snowmelt enables females to produce their first clutch earlier and gives them enough time to

182 produce a second clutch before the season ends. It is possible that climate change is altering the

183 reproductive strategy of $P$. glacialis, allowing females to produce second clutches for the first time.

184 However, given that Arctic wolf spiders have been shown to respond rapidly to environmental

185 conditions and given the broad distribution of individual species [34], it seems plausible that this

186 species is already adapted to opportunistically reproduce a second time when conditions allow.

187 Although our study was limited to a single site, Zackenberg is at the northern edge of the range of

$188 P$. glacialis and one of the most climatically extreme locations inhabited by this species. Thus, it is

189 likely that $P$. glacialis and possibly other wolf spider species are also already producing second

190 clutches at lower arctic and boreal latitudes. Similar studies at other sites and for other invertebrate

191 species are needed to unravel the ubiquity of climate-induced shifts in voltinism and the potential

192 ecological consequences.

193 We found a difference in the mean date of capture of first and second clutches of

194 about 20 days. This period is less than previous reports of a 30-day interval between the production

195 of first and second clutches in temperate wolf spiders [32], but it may be related to the long daily

196 hours of incident solar radiation at high latitudes. The growing season at Zackenberg is extremely

197 short and P. glacialis could be adapted to rapidly respond to favorable conditions by producing

198 second clutches whenever opportunity allows. It is possible that some of the clutches that were

199 assigned as second clutches could have been from females who lost their first egg sacs (e.g. due to

200 predation from birds). In such cases, the production of a second, smaller clutch would happen

201 earlier in the season and would reduce our estimate of a time difference. Still, the combination of 
202

203

evidence presented here strongly suggest that $P$. glacialis are indeed producing second clutches in years with earlier snowmelt at our High-Arctic site.

Increased reproductive output can increase population size if other factors such as competition or predation are not limiting population growth. Yet, we have not observed significant changes in population size of $P$. glacialis at this site during the study period [27]. Thus, it is unclear whether increased reproductive rates associated with the production of second clutches will have population-level consequences for this species in the future. Recent evidence from our field site suggests that $P$. glacialis is not food limited [47], nor are its populations affected by parasitism as in other arctic wolf spiders [48, 49]. However, wolf spiders are density-dependent cannibals [e.g., 50, $51,52]$, and a lack of observed population growth could be a result of increased intraspecific competition with rising reproductive rates [53]. As $P$. glacialis is the largest invertebrate predator at our site, further studies should address whether there are implications of higher reproductive rates among the spiders for prey populations. If prey populations do not respond in a similar way to earlier snowmelt, they might be negatively affected by an increasing predation pressure as top-down forces appears to be the main control mechanism of tundra food webs [26, 54, 55]. Smaller arthropod predators, such as other spiders, might also suffer from the increase in abundance of $P$. glacialis due to the limited differentiation in diet between predators in the High Arctic $[27,53,56]$. Studies of the effects on population dynamics, cascading effects in food webs, and repercussions on ecosystem function, continue to establish wolf spiders as key model organisms for the study of Arctic climate change effects.

\section{ACKNOWLEDGEMENTS}


224 Access to spider specimens and climate data from the Greenland Ecosystem Monitoring program is 225 greatly appreciated. Spider specimens are curated by the Natural History Museum, Aarhus,

226 Denmark.

227 


\section{References}

1. Thackeray S.J., Henrys P.A., Hemming D., Bell J.R., Botham M.S., Burthe S., Helaouet P., Johns D.G., Jones I.D., Leech D.I., et al. 2016 Phenological sensitivity to climate across taxa and trophic levels. Nature 535(7611), 241-245. (doi:10.1038/nature18608). 2. Høye T.T., Post E., Meltofte H., Schmidt N.M., Forchhammer M.C. 2007 Rapid advancement of spring in the High Arctic. Curr Biol 17(12), R449-451. (doi:10.1016/j.cub.2007.04.047). 3. Parmesan C. 2006 Ecological and evolutionary responses to recent climate change. Annual Review of Ecology Evolution and Systematics 37, 637-669. (doi:DOI 10.1146/annurev.ecolsys.37.091305.110100). 4. Visser M.E., Both C. 2005 Shifts in phenology due to global climate change: the need for a yardstick. Proceedings of the Royal Society B: Biological Sciences 272(1581), 2561-2569. (doi:10.1098/rspb.2005.3356).

5. Miller-Rushing A.J., Høye T.T., Inouye D.W., Post E. 2010 The effects of phenological mismatches on demography. Phil Trans R Soc B 365(10.1098/rstb.2010.014), 31773186.

6. Ramula S., Johansson J., Linden A., Jonzen N. 2015 Linking phenological shifts to demographic change. Clim Res 63(2), 135-144. (doi:10.3354/cr01289).

7. Jönsson A.M., Appelberg G., Harding S., Bärring L. 2009 Spatio-temporal impact of climate change on the activity and voltinism of the spruce bark beetle, Ips typographus. Glob Change Biol 15(2), 486-499. (doi:10.1111/j.1365-2486.2008.01742.x).

8. Mitton J.B., Ferrenberg S.M. 2012 Mountain Pine Beetle Develops an Unprecedented Summer Generation in Response to Climate Warming. The American Naturalist 179(5), E163E171. (doi:10.1086/665007).

9. Altermatt F. 2010 Climatic warming increases voltinism in European butterflies and moths. Proceedings of the Royal Society B-Biological Sciences 277(1685), 1281-1287. (doi:10.1098/rspb.2009.1910).

10. Møller A.P., Flensted-Jensen E., Klarborg K., Mardal W., Nielsen J.T. 2010 Climate change affects the duration of the reproductive season in birds. J Anim Ecol 79(4), 777-784. (doi:10.1111/j.1365-2656.2010.01677.x). 11. Hovel R.A., Carlson S.M., Quinn T.P. 2017 Climate change alters the reproductive phenology and investment of a lacustrine fish, the three-spine stickleback. Glob Change Biol 23(6), 2308-2320. (doi:10.1111/gcb.13531).

12. Miller-Rushing A.J., Høye T.T., Inouye D.W., Post E. 2010 The effects of phenological mismatches on demography. Philosophical Transactions: Biological Sciences 365(1555), 3177-3186. (doi:10.1098/rstb.2010.0148).

13. Baba Y.G., Walters R.J., Miyashita T. 2013 Complex latitudinal variation in the morphology of the kleptoparasitic spider Argyrodes kumadai associated with host use and climatic conditions. Popul Ecol 55(1), 43-51. (doi:10.1007/s10144-012-0334-5).

14. Bayram A. 2000 A study of egg production in three species of wolf spiders (Araneae, Lycosidae), Pardosa amentata, P. palustris, and P. pullata in the field. Israel Journal of Ecology and Evolution 46(4), 297-303. (doi:10.1560/0AM1-NTRX-V05V-3JBD). 15. IPCC. 2013 Climate change 2013: the physical science basis. Contribution of working group I to the fifth assessment report of the intergovernmental panel on climate change.

16. Høye T.T., Forchhammer M.C. 2008 Phenology of High-Arctic Arthropods: Effects of Climate on Spatial, Seasonal, and Inter-Annual Variation. 40, 299-324. (doi:10.1016/s00652504(07)00013-x). 
17. Høye T.T., Eskildsen A., Hansen R.R., Bowden J.J., Schmidt N.M., Kissling W.D. 2014 Phenology of high-arctic butterflies and their floral resources: Species-specific responses to climate change. 18. Tulp I., Schekkerman H. 2008 Has Prey Availability for Arctic Birds Advanced with Climate Change? Hindcasting the Abundance of Tundra Arthropods Using Weather and Seasonal Variation. Arctic 61(1), 48-60.

19. Bolduc E., Casajus N., Legagneux P., McKinnon L., Gilchrist H.G., Leung M., Morrison R.I.G., Reid D., Smith P.A., Buddle C.M., et al. 2013 Terrestrial arthropod abundance and phenology in the Canadian Arctic: modelling resource availability for Arctic-nesting insectivorous birds. Can Entomol 145(2), 155-170. (doi:10.4039/tce.2013.4).

20. Hansen R.R., Hansen O.L.P., Bowden J.J., Treier U.A., Normand S., Høye T.T. 2016 Meter scale variation in shrub dominance and soil moisture structure Arctic arthropod communities. Peerj 4, ARTN e2224. (doi:10.7717/peerj.2224).

21. Høye T.T., Bowden J.J., Hansen O.L.P., Hansen R.R., Henriksen T.N., Niebuhr A., Skytte M.G. 2017 Elevation modulates how Arctic arthropod communities are structured along local environmental gradients. Polar Biol. (doi:10.1007/s00300-017-2204-2).

22. Asmus A., Koltz A., McLaren J., Shaver G.R., Gough L. 2017 Long-term nutrient addition alters arthropod community composition but does not increase total biomass or abundance. Oikos, n/a-n/a. (doi:10.1111/oik.04398).

23. Rich M.E., Gough L., Boelman N.T. 2013 Arctic arthropod assemblages in habitats of differing shrub dominance. Ecography 36(9), 994-1003. (doi:10.1111/j.1600-0587.2012.00078.x). 24. Kuusk A.-K., Ekbom B. 2012 Feeding habits of lycosid spiders in field habitats. $J$ Pest Sci 85(2), 253-260. (doi:10.1007/s10340-012-0431-4).

25. Lawrence K.L., Wise D.H. 2000 Spider predation on forest-floor Collembola and evidence for indirect effects on decomposition. Pedobiologia - International Journal of Soil Biology 44(1), 33-39. (doi:10.1078/S0031-4056(04)70026-8).

26. Koltz A.M., Asmus A., Gough L., Pressler Y., Moore J.C. 2017 The detritus-based microbial-invertebrate food web contributes disproportionately to carbon and nitrogen cycling in the Arctic. Polar Biol. (doi:10.1007/s00300-017-2201-5).

$27 . \quad$ Bowden J.J., Hansen O.L.P., Olsen K., Schmidt N.M., Hoye T.T. 2018 Drivers of inter-annual variation and long-term change in High-Arctic spider species abundances. Polar Biol 41(8), 1635-1649. (doi:10.1007/s00300-018-2351-0).

28. Asmus A.L., Chmura H.E., Hoye T.T., Krause J.S., Sweet S.K., Perez J.H., Boelman N.T., Wingfield J.C., Gough L. 2018 Shrub shading moderates the effects of weather on arthropod activity in arctic tundra. Ecol Entomol 43(5), 647-655. (doi:10.1111/een.12644).

29. Pickavance J.R. 2001 Life-cycles of four species of Pardosa (Araneae, Lycosidae) from the island of Newfoundland, Canada. J Arachnol 29, 367-377.

30. $\quad$ Buddle C.M. 2000 Life history of Pardosa moesta and Pardosa mackenziana (Araneae, Lycosidae) in central Alberta, Canada. J Arachnol 28(3), 319-328.

31. Zoltán R., Balázs K., Ferenc S. 2017 Effect of weather conditions on cohort splitting in a wolf spider species. The Journal of Arachnology 45(3), 444-447. (doi:10.1636/JoA-S-17008.1). 32. Brown C.A., Sanford B.M., Swerdon R.R. 2003 Clutch Size and Offspring Size in the Wolf Spider Pirata Sedentarius (Araneae, Lycosidae). J Arachnol 31(2), 285-296. (doi:10.1636/m01-62).

33. Hein N., Feilhauer H., Löffler J., Finch O.-D. 2015 Elevational Variation of Reproductive Traits in FivePardosa(Lycosidae) Species. Arct Antarct Alp Res 47(3), 473-479. (doi:10.1657/aaar0013-111). 
324 34. Dondale C.D., Redner J.H. 1990 The insects and arachnids of Canada. Part 17. The

325 wolf spiders, nurseryweb spiders, and lynx spiders of Canada and Alaska. Araneae: Lycosidae,

326 Pisauridae, and Oxyopidae, Agriculture Canada.

327

328

329

35. Bowden J.J., Buddle C.M. 2012 Life history of tundra-dwelling wolf spiders

(Araneae: Lycosidae) from the Yukon Territory, Canada. Canadian Journal of Zoology 90(6), 714721. (doi:10.1139/z2012-038).

$33036 . \quad$ Blanckenhorn W.U. 2000 The Evolution of Body Size: What Keeps Organisms

331 Small? The Quarterly Review of Biology 75(4), 385-407.

332

333

334

335

336

337

338

339

340

341

342

343

344

345

346

347

37. Reed D.H., Nicholas A.C. 2008 Spatial and temporal variation in a suite of life-history traits in two species of wolf spider. Ecol Entomol 33(4), 488-496. (doi:10.1111/j.13652311.2008.00994.x).

38. Fritz R.S., Morse D.H. 1985 Reproductive Success and Foraging of the Crab Spider Misumena vatia. Oecologia 65(2), 194-200. (doi:10.1007/BF00379217).

39. Bowden J.J., Høye T.T., Buddle C.M. 2013 Fecundity and sexual size dimorphism of wolf spiders (Araneae: Lycosidae) along an elevational gradient in the Arctic. Polar Biol 36(6), 831-836. (doi:DOI 10.1007/s00300-013-1308-6).

40. Høye T.T., Hammel J.U. 2010 Climate change and altitudinal variation in sexual size dimorphism of arctic wolf spiders. Climate Research 41(3), 259-265.

41. Høye T.T., Hammel J.U., Fuchs T., Toft S. 2009 Climate change and sexual size dimorphism in an Arctic spider. Biol Lett 5(4), 542-544. (doi:10.1098/rsbl.2009.0169).

42. $\quad$ Schmidt N.M., Reneerkens J., Christensen J.H., Olesen M., Roslin T. 2019 An ecosystem-wide reproductive failure with more snow in the Arctic. PLoS Biol 17(10), e3000392. (doi:10.1371/journal.pbio.3000392).

43. Bowden J.J., Eskildsen A., Hansen R.R., Olsen K., Kurle C.M., Høye T.T. 2015 HighArctic butterflies become smaller with rising temperatures. Biol Lett 11, 20150574. (doi:10.1098/rsbl.2015.0574).

350 44. Høye T.T., Hammel J.U., Fuchs T., Toft S. 2009 Climate change and sexual size 351 dimorphism in an arctic spider. Biol Lett 5, 542-544.

$35245 . \quad$ Hendrickx F., Maelfait J.-P. 2003 LIFE CYCLE, REPRODUCTIVE PATTERNS

353 AND THEIR YEAR-TO-YEAR VARIATION IN A FIELD POPULATION OF THE WOLF

354 SPIDER < span class="genus-species">PIRATA PIRATICUS </span> (ARANEAE,

355 LYCOSIDAE). The Journal of Arachnology 31(3), 331-339, 339.

$35646 . \quad$ Simpson M.R. 1993 Reproduction in two species of arctic arachnids, Pardosa 357 glacialis and Alopecosa hirtipes Can J Zool 71, 451-457.

$35847 . \quad$ Visakorpi K., Wirta H.K., Ek M., Schmidt N.M., Roslin T. 2015 No detectable trophic 359 cascade in a high-Arctic arthropod food web. Basic Appl Ecol 16(7), 652-660.

360 (doi:10.1016/j.baae.2015.06.003).

$36148 . \quad$ Bowden J.J., Buddle C.M. 2012 Egg sac parasitism of Arctic wolf spiders (Araneae: 362 Lycosidae) from northwestern North America. J Arachnol 40(3), 348-350.

363 49. Koltz A.M., Culler L.E., Bowden J.J., Post E., Hoye T.T. 2019 Dominant Arctic 364 Predator Is Free of Major Parasitoid at Northern Edge of Its Range. Frontiers in Ecology and 365 Evolution 7. (doi:10.3389/fevo.2019.00250).

$36650 . \quad$ Buddle C.M., Walker S.E., Rypstra A.L. 2003 Cannibalism and density-dependent 367 mortality in the wolf spider Pardosa milvina (Araneae: Lycosidae). Canadian Journal of Zoology 368 81(8), 1293-1297. (doi:10.1139/z03-124).

369 51. Wise D.H. 2006 Cannibalism, food limitation, intraspecific competition, and the 370 regulation of spider populations. Annu Rev Entomol 51, 441-465. 
$371 \quad$ 52. Wagner J.D., Wise D.H. 1996 Cannibalism Regulates Densities of Young Wolf 372 Spiders: Evidence From Field and Laboratory Experiments. Ecology 77(2), 639-652.

373 (doi:10.2307/2265637).

$37453 . \quad$ Koltz A.M., Wright J.P. in press Impacts of female body size on cannibalism and 375 juvenile abundance in a dominant arctic spider. J Anim Ecol. (doi:10.1111/1365-2656.13230).

376 54. Legagneux P., Gauthier G., Berteaux D., Bêty J., Cadieux M.C., Bilodeau F., Bolduc 377 E., McKinnon L., Tarroux A., Therrien J.F., et al. 2012 Disentangling trophic relationships in a 378 High Arctic tundra ecosystem through food web modeling. Ecology 93(7), 1707-1716.

379 (doi:10.1890/11-1973.1).

380 55. $\quad$ Gauthier G., Berteaux D., Bêty J., Tarroux A., Therrien J.-F., McKinnon L., 381 Legagneux P., Cadieux M.-C. 2011 The Tundra Food Web of Bylot Island in a Changing Climate 382 and the Role of Exchanges between Ecosystems. Ecoscience 18(3), 223-235. (doi:10.2980/18-3383 3453).

$384 \quad 56 . \quad$ Wirta H.K., Weingartner E., Hamback P.A., Roslin T. 2015 Extensive niche overlap 385 among the dominant arthropod predators of the High Arctic. Basic Appl Ecol 16(1), 86-92.

386 (doi:DOI 10.1016/j.baae.2014.11.003).

387 
389

390

391

392

393

394

395

396

397

398

399

400

401

402

403

404

405

406

407

408

409

410

411

\section{Figure legends}

\section{Figure 1}

Frequency distribution of clutch sizes in the wolf spider Pardosa glacialis across 1069 egg sacs collected in pitfall traps during 1996-2014 at Zackenberg, North-East Greenland. The solid line represents a locally weighted smoothing with a span parameter $=0.2$ and identifies a local minimum at a clutch size of 47 eggs used to separate first and second clutches, as indicated by the vertical hatched line.

\section{Figure 2}

Seasonal variation in total egg sac collection across the study period (grouped by seven day periods). Dates are presented as day of year since 1 January. The white section of each bar indicates clutches with more than 47 eggs (first clutches) and the black sections are for those clutches with 47 or less eggs (second clutches).

\section{Figure 3}

The proportion of second clutches out of total number of clutches in a given year regressed against a) average date of snowmelt (day of year since January 1) across the study plots (slope = -

$\left.0.0150 \pm 0.0038, \mathrm{t}_{16}=-3.949, \mathrm{p}=0.0012\right)$ and $\left.\mathrm{b}\right)$ sampling year $\left(\right.$ slope $=0.0182 \pm 0.0075, \mathrm{t}_{16}=2.418$, $\mathrm{p}=0.028)$

\section{Figure 4}

Relationship between clutch size and body size of the mother for each habitat type (wet, mesic, and arid) for (A) first and (B) second clutches. The relationships are significant for first clutches, but not 
412 for second clutches (see text for details). Body size of the mother was estimated as width of the 413 carapace (in millimeters).

414 


\section{6}

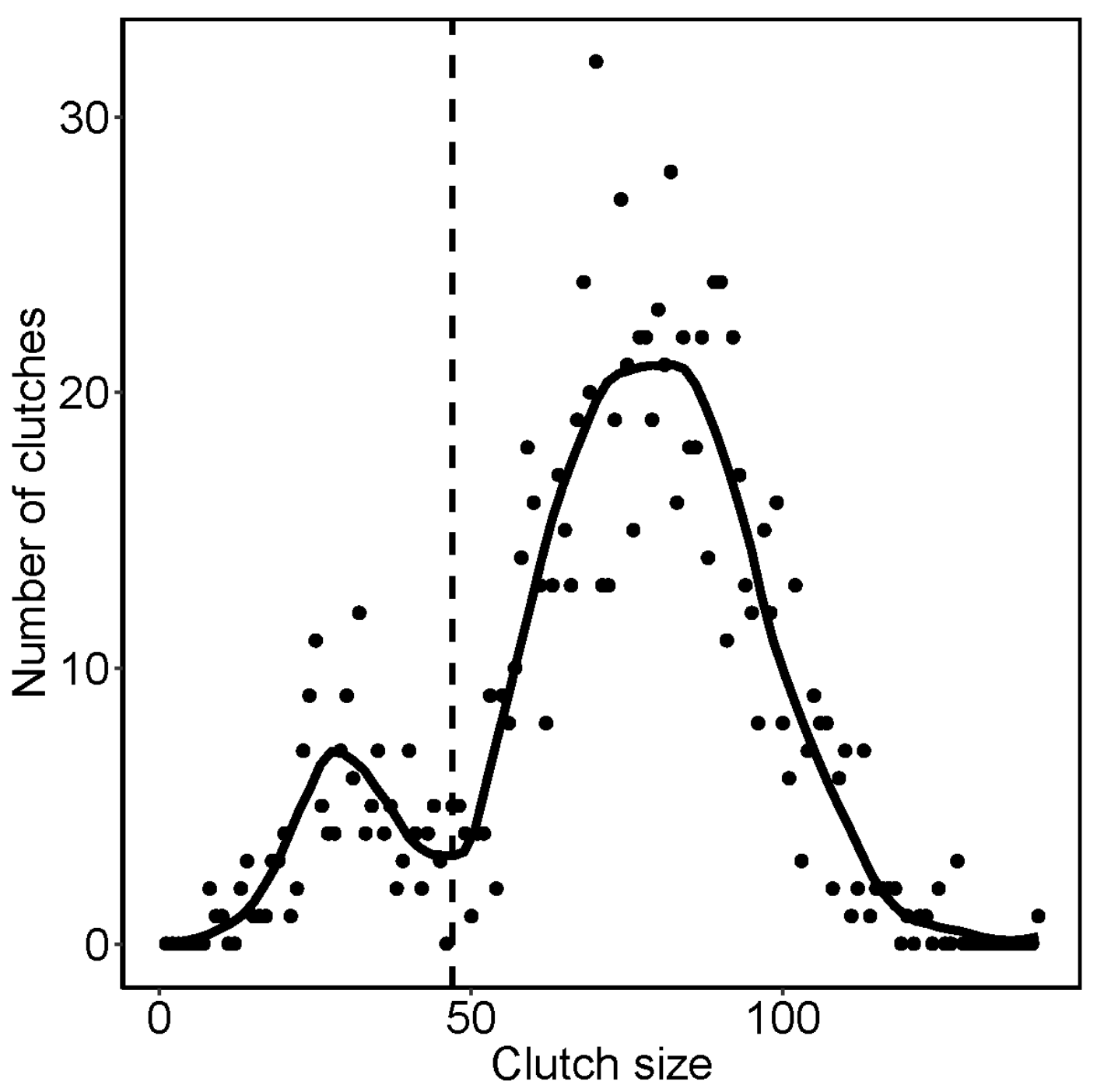




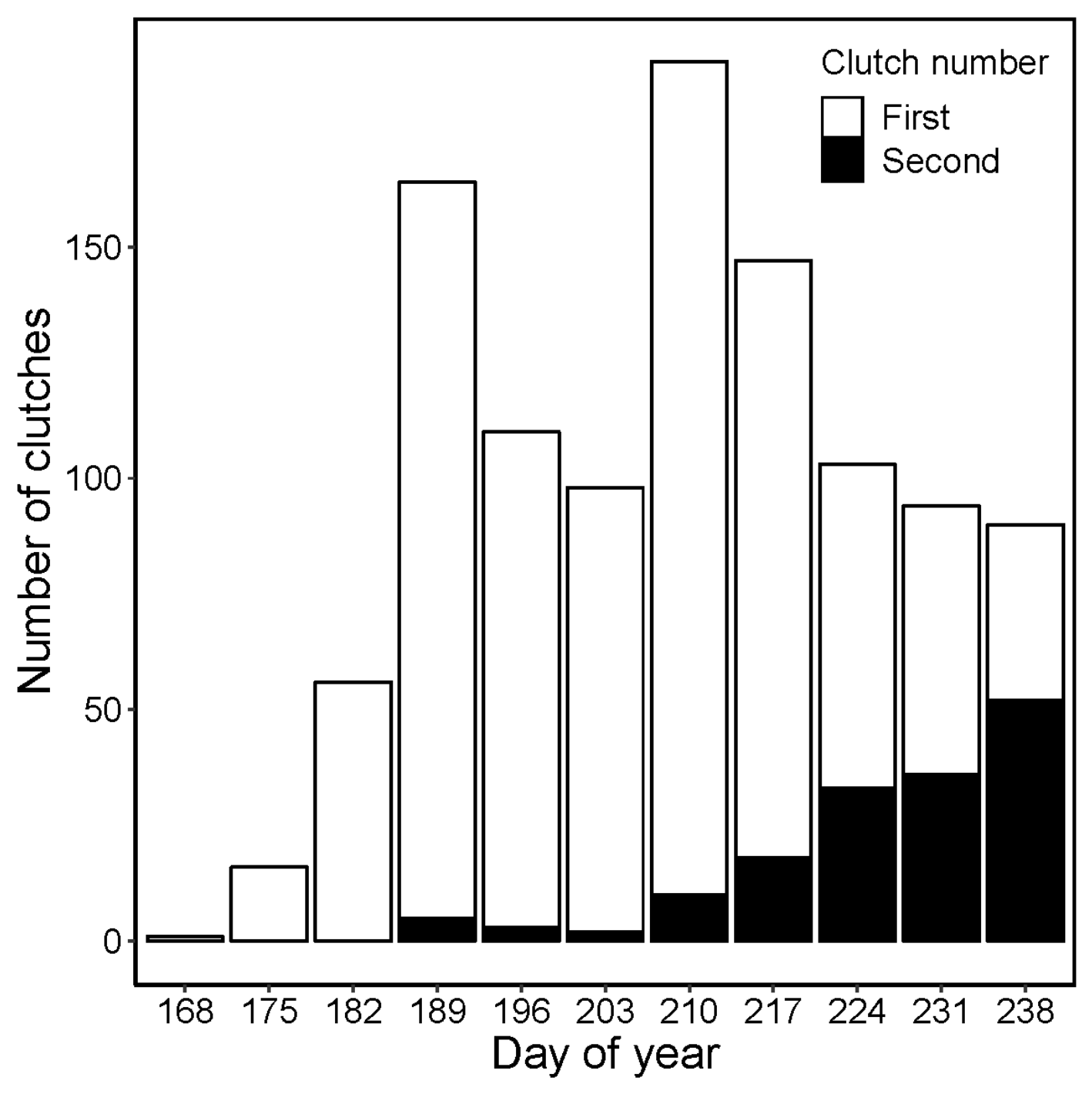




\section{$421 \quad$ Figure 3}

422
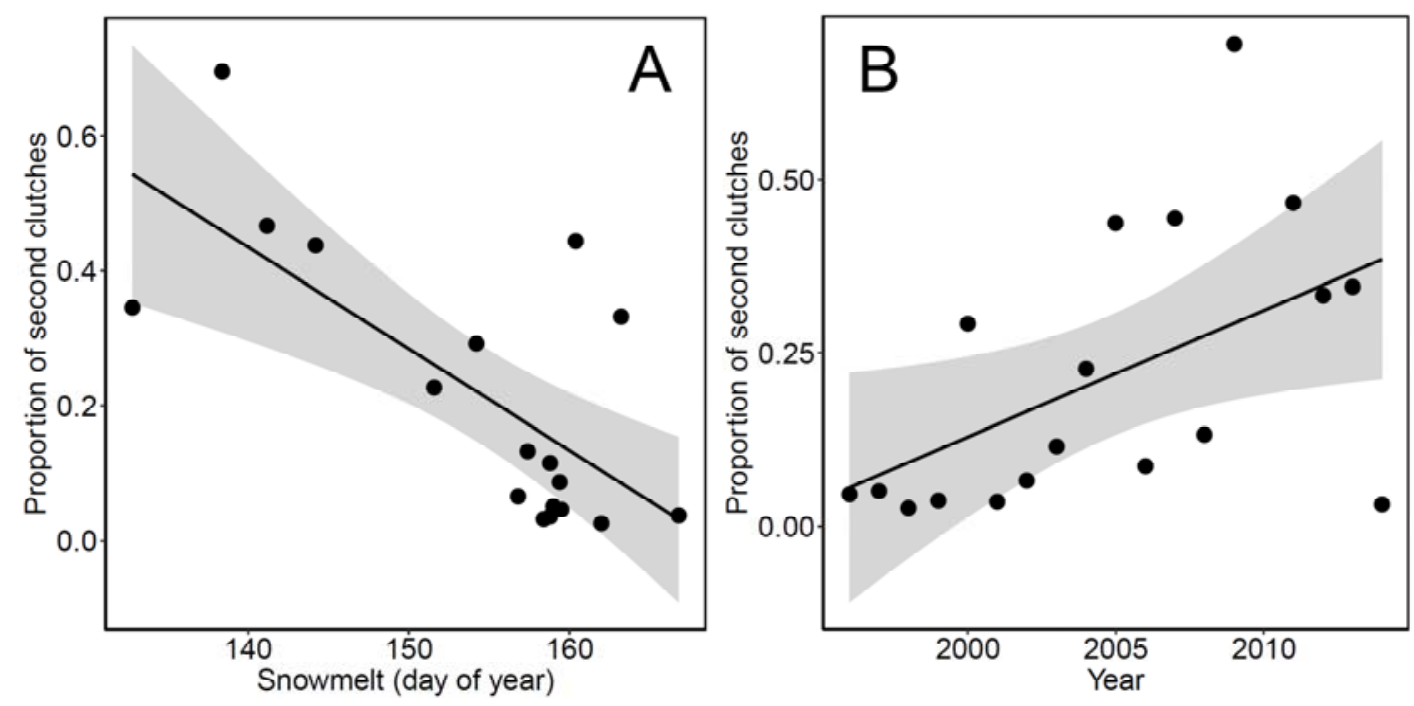
bioRxiv preprint doi: https://doi.org/10.1101/2020.04.30.070029; this version posted May 2, 2020. The copyright holder for this preprint (which was not certified by peer review) is the author/funder. All rights reserved. No reuse allowed without permission.

\section{Figure 4}

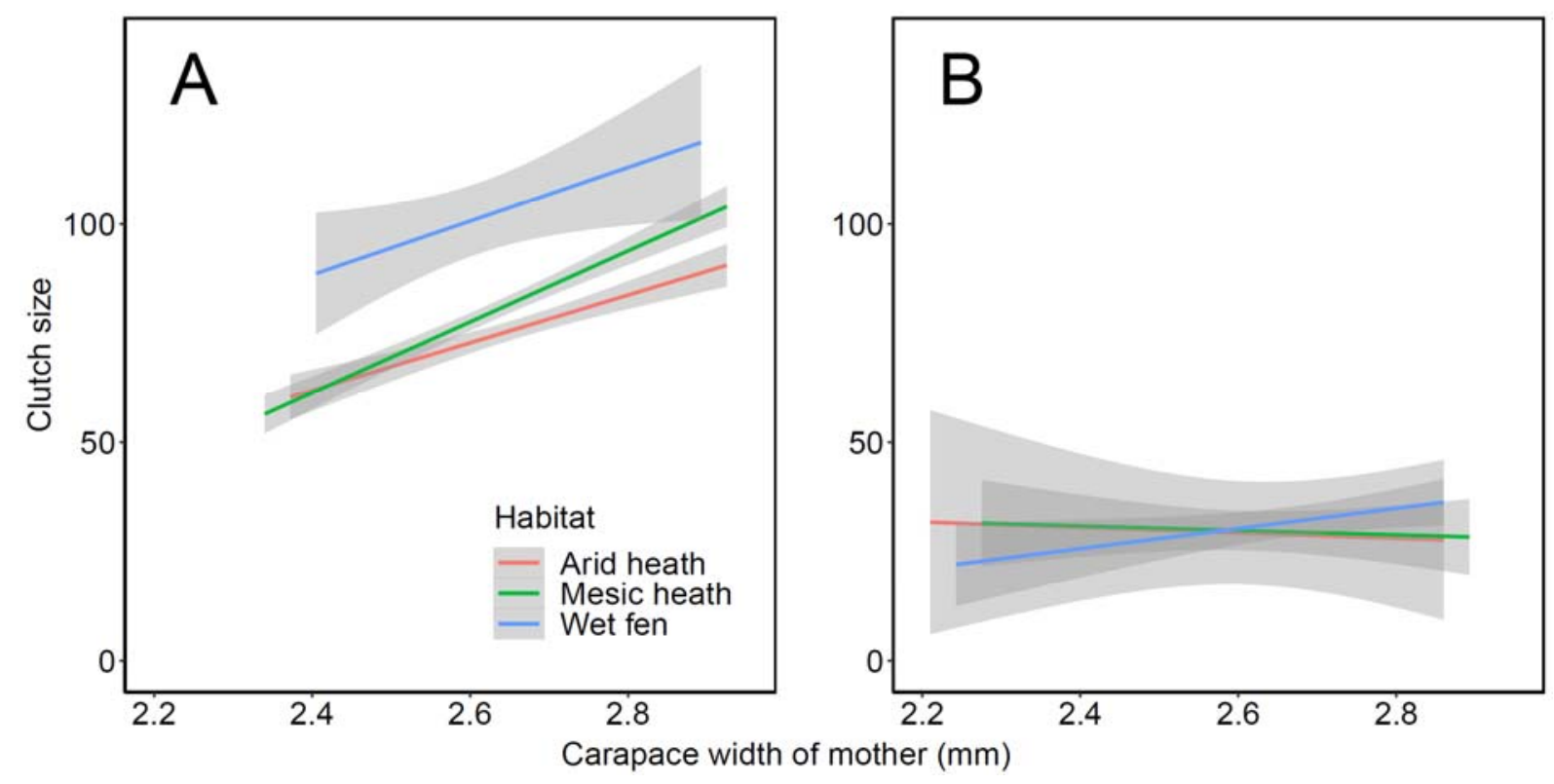

425 